\title{
Religion and social transformation: A case study from South Africa
}

\author{
Johannes C. Erasmus, University of Stellenbosch \\ Introduction
}

There are several reasons, from our point of view, why this topic is relevant. In February 2001 the Unit for Religion and Development Research (URDR) was formally founded within the Department of Practical Theology and Missiology at the Faculty of Theology at the University of Stellenbosch. The URDR's mission is to empower faithbased communities towards achieving self-reliant sustainable development and outcomes through research, theorizing and training. As the name indicates, the agenda for our research activities is both religion and development, especially the nexus between the two concepts. There is a distinct connection between development and social transformation (see Castles, 1999:2ff.) and hence a relation between religion and social transformation, the topic of this paper. Secondly, Transformation Africa,2 a network organisation in South Africa mobilising prayer throughout South Africa and the world, contracted the Unit to conduct research in the Cape Peninsula. It is the mission of this organisation to effect transformation in communities throughout Africa.

Thirdly, South Africa is considered a very religious country. In South Africa the church is the strongest and most influential non-governmental organisation (NGO) reaching, on average, 63\% of the Christian population weekly (Erasmus \& Hendriks, 2003). Neither the government nor any other NGO can reach and influence the public more regularly and consistently than FBOs. Moreover, more than three quarters of the population have indicated that they are affiliated with the Christian religion (79.8\% - Census 2001). Affiliation to the Christian religion, for example, increased from 45.7\% in 1911 to $79.8 \%$ in 2001(see Hendriks, 2003; Hendriks \& Erasmus, 2001; Erasmus \& Hendriks, 2003; and Erasmus, 2000).

There are approximately 43,000 Christian faith communities (Froise 1999:37) in South Africa and the infrastructure of these churches reaches every corner of our country. In rating South African social institutions, the Human Science Research Council (HSRC) (2000) found that the public's view of the church received the highest percentage of trust ( $74 \%$ in 2000 ). Second to the church was the Electoral Commission at $50 \%$ ! This signifies that churches enjoy significant credibility. The well-being of communities depends largely on the harnessing of their citizens' contributions. In many of these communities the majority of the residents are people of faith. It is inevitable that most of these contributions, be they physical, emotional or other resources, come from people of faith. No one who wants to mobilise these contributions towards the transformation of the community can ignore the pervasiveness of these faith communities. Even though religion has this huge potential, the context of religion in South Africa is more complex than this. It has been argued that religion often inhibits change and in many cases it instinctively protects the status quo. Indeed, this is also true in South Africa.

Lastly, since the mid-1980s South Africa has gone through far-reaching transformations. The two most prominent ones were getting rid of the yoke of apartheid and the entering into a new democratic dispensation with the first democratic elections held in 1994. The South African population are currently celebrating the 10th anniversary of these elections. Since 1994 the country has also developed and accepted one of the most liberal constitutions in the world. South Africa is now governed according to a constitution in which human rights are spelled out. The country as a whole and local communities are still grappling with the realities of living a postapartheid democracy. It is evident, however, that daunting challenges still face South Africa after the miracle of its peaceful transition. Overwhelming poverty and poverty-related problems, such as the HIV/Aids pandemic, face Africa. South Africa is comprised of both a rich and a poor world (Terreblanche, 2002). Previously, the apartheid laws marked boundaries between these two worlds. Now, new boundaries are developing along, inter alia, political power and class-related lines. Social transformation, implying the way "society and culture change in response to such factors as economic growth, war or political upheavals" (Castles, 1999:1), is particularly 
relevant to the continuing transformation of communities in post-apartheid South Africa.

The hypothesis of this paper is that religion does play a significant role in transformation processes. Hence, this paper will further develop this hypothesis, firstly, by unpacking the concept of social transformation. Secondly, the question regarding the contribution of religion as a force in change will be addressed. The author is an ordained minister and affiliated with Christianity, and for this reason the focus will be the Christian religion. Thirdly, a case study from South Africa will be considered and the question asked whether the Christian religion can influence the process of social transformation and if so under what circumstances.

\section{The concept of social transformation}

Liz Stanley (1997:1), editor of Sociological Research Online, illustrates the woolliness surrounding the concept in her call for papers on the theme of social transformation: And of course the notion of 'social transformation' which stands at the head of this editorial call for papers does not stand apart here. Once we start to ask simple questions - such as what is being transformed and as compared against what? at what point can 'transformation' be discerned and what is the baseline from which it takes off? who defines this term and how is it used? why is it applied to some states and conditions (usually those that don't have 'it') but not others? its implicatedness

becomes immediately apparent. Once more the conjunction of the political and the epistemological is impressed upon us, and once more the questions raised have crucial consequence in the world as well as in the discipline.

The concept of social transformation must be distinguished from that of development. There is a strong notion that development was largely conceived and characterised by the belief in progression, based on the odernisation theory found in highly developed western countries (Castles, 1999; Taylor, 1998). Development is based on the principle of quantitative growth measured in GDP per capita, while transformation is more concerned with qualitative growth, i.e. sustainable environments measured with the Human Development Index. The idea of development "is the most recent stage of the Enlightenment notion of human progress as a continual process of internal and external expansion based on values of rationality, secularity and efficiency" (Castles, 1999:2).

Social transformation does not imply any predetermined outcomes, nor is the processes essentially positive (Castles, 1999:1). Transformation in the South African context refers to the transition from exclusion to inclusion in all spheres of life (Wint \& Ngcobo, 2000: 93). The previously disadvantaged and excluded people in communities are now included in social, political and economical opportunities, structures and power. In an attempt to define the concept of social transformation, we find Groenewald (following Barnhart \& Barnhart, 1982) very helpful. He defines the concept as follows: “...to transform is to change in form or appearance; in condition, nature or character. The social is concerned with human beings in their relations to each other, their living conditions, and living together in organized communities" (1999: 18). Castles also makes an important point when he argues that social transformation happens in response to factors such as the economy, war and political upheavals (Castles, 1999:1). In other words, social transformation describes how global processes of change influence local and national communities (Castles, 1999:5). Applying these guidelines to the South African context and picking up Wint and Ngcobo's point of inclusion means that social transformation in South Africa describes the country's and different communities' response to being included after a long period of being excluded socially, economically and politically.

Lastly, the use of social transformation as an analytical framework is based on a number of suppositions:

1. Social transformation is both a "micro and macro phenomenon; it affects interpersonal relationships as well as societal and international relations... Sociology tends to take a macro view of social transformation. Broad historical and evolutionary patterns and trends are therefore described" (Groenewald, 2000: 18). Further evidence of the above arguments are given by Drucker (1994), who argues that the concept of social transformation is determined by two fundamental aspects, namely global social transformations in the last century and local discourses in social transformation the last twenty years. "No century in recorded history has experienced so many social transformations and such radical ones as the twentieth century" (Drucker, 1994: 53).

2. Social transformation "affects all types of society in both developed and less-developed regions" (Castles, 1999:6). Groenewald argues (he finds support from Curry, Jiobu \& Schwirian, 1997) that a major qualitative 
change in the nature of social relations in societies has been the shift from predominantly communal to predominantly associational societies (see table below).

\begin{tabular}{|c|c|}
\hline $\begin{array}{l}\text { Characteristics of } \\
\text { communal societies }\end{array}$ & Characteristics of associational societies \\
\hline $\begin{array}{l}\text { Limited division of } \\
\text { labour }\end{array}$ & $\begin{array}{l}\text { Complex division of labour in all } \\
\text { activities }\end{array}$ \\
\hline $\begin{array}{l}\text { Family, clan, tribe \& } \\
\text { village basic social } \\
\text { units }\end{array}$ & $\begin{array}{l}\text { Associations, organizations \& } \\
\text { corporations basic units }\end{array}$ \\
\hline $\begin{array}{l}\text { Personalized } \\
\text { relationships }\end{array}$ & $\begin{array}{l}\text { Relationships formalized, transitory, less } \\
\text { personal }\end{array}$ \\
\hline $\begin{array}{l}\text { Economy based on } \\
\text { commodities in } \\
\text { nearby habitat }\end{array}$ & $\begin{array}{l}\text { Economy based on manufacturing \& } \\
\text { related activities }\end{array}$ \\
\hline $\begin{array}{l}\text { Overall level of } \\
\text { technology is low }\end{array}$ & Technology is high \\
\hline $\begin{array}{l}\text { Political institutions non } \\
\text { bureaucratic }\end{array}$ & $\begin{array}{l}\text { Political institutions complex \& } \\
\text { bureaucratic }\end{array}$ \\
\hline $\begin{array}{l}\text { Limited system of social } \\
\text { stratification }\end{array}$ & $\begin{array}{l}\text { Complex social stratification - large } \\
\text { middle class }\end{array}$ \\
\hline Rich ceremonial life & $\begin{array}{l}\text { Rationality prized, diminished role of } \\
\text { spirituality }\end{array}$ \\
\hline $\begin{array}{l}\text { Limited contact with } \\
\text { other societies }\end{array}$ & $\begin{array}{l}\text { Society part of global network of } \\
\text { societies }\end{array}$ \\
\hline
\end{tabular}

Table 1: characteristics of communal and associational societies

\begin{tabular}{|l|l|}
\hline Life is & Life is \\
Less complex & More complex \\
Less diverse & More diverse \\
More traditional & Less traditional \\
More personal & More impersonal \\
\hline
\end{tabular}

Source: Groenewald, 2000:19 (from Curry, Jiobu \& Schwirian, 1997:44).

3. The processes that facilitate these major social transformations include industrialization, urbanization, rationalization, bureaucratization and globalization (Groenewald, 2000:18). Social transformation is a framework for "understanding the way contemporary processes of global change affect local communities and national societies throughout the world" (Castles, 1999:5).

4. There is a dialectical relation between globalization and social transformation. Castles calls social transformation the "antithesis of globalization" (Castles, 1999:1). Social transformation is both an integral part of globalization, but also part of a process that undermines its central ideologies. Response to globalization is thus not only a question of adaptation but also resistance. It is against these forces of globalization and capitalist restructuring that resistance identities develop (Groenewald, 2000:27). Groenewald explains this resistance against globalisation as the process of localization (2000: 26ff.). Of particular interest is the distinction between resistance identities and project identities made by Castells (1997:359 and 6-12). Castells elucidates further on the nature of these identities: Along with the technological revolution, the transformation of capitalism, and the demise of statism, we have experienced, in the last quarter of the century, the widespread surge of powerful expressions of collective identity that challenge globalization and cosmopolitanism on behalf of cultural singularity and people's control over their lives and environment.

These expressions are multiple, highly diversified, following the contours of each culture, and of historical sources of formation of each identity. They include proactive movements, aiming at transforming human relationships at their most fundamental level, such as feminism and environmentalism. But they also include a whole array of reactive movements that build trenches of resistance on behalf of God, nation, ethnicity, family, locality." (1997:2, my italics) The backdrop to the formation of these resistance identities is the emergence of the social network. The network society is the rising implication of modern society moving from an industrial to an informational society (Castells, 1996:13-22).

"The material base of the network society is an electronic communication network that provides the cyberspace for timeless flows. The qualitative difference of the network society to its predecessors is its networking logic: the power of flows takes precedence over the flows of power" (Groenewald 2000:25). Groenewald (2000:27) concludes that it is precisely these social movements that hold the potential to promote change. They include people such as ecologists, feminists, religious fundamentalists, nationalists and localists. 
These identities must be social mobilizers. They can either be prophets, symbolic faces of the insurgency who "declare the path, affirm the values, and act as symbol senders, becoming a symbol themselves, so that the message is inseparable from the messenger" (Groenewald, 2000:27). Alternatively, they can be a "networking, decentered form of organization and intervention, characteristic of the new social movements, mirroring, and counteracting, the networking logic of domination in the informational society" (Groenewald, 2000:28).

Thus to change human society, the meanings of symbols or the symbols themselves need to change. For this to come about there needs to be collective action, which includes the mediation of meaning (Groenewald, 2000:28).

5. Personal or inner change, on the one hand, and social or outer change, on the other, are indivisibly linked (Edwards \& Sen, 2000:605). Change processes are energized by deep-rooted personal transformation which can also fuel the search for more humane social and economic systems (2000:610; see also Tyndale, 2000:1516). For societies to be sustainable there need to be deeper changes, which encourage people "to conserve scarce resources, share their wealth and opportunities, protect each other's rights, and co-operate to advance the 'common good', namely the long-term health and welfare of the planet and its social fabric on which all our futures depend" (Edwards \& Sen, 2000:606).

Their perspective on change is that all social systems rest on three bases: a set of principles, ethics and values; a set of processes, which are the functioning mechanisms and institutions that undergird that system; and the subjective states that constitute our inner being, personal feelings and intuitions (Edwards \& Sen, 2000:606). Where changes have occurred, the three bases have integrated and worked together (Edwards \& Sen, 2000:607).

From a functional point of view, they regard NGOs (including churches and other faith-based groups in civil society) as the likely organisations to facilitate these integrated changes. They suggest ways in which NGOs can foster change, firstly, in their programme of activities, secondly, in their fund-raising and constituency building, and thirdly, in their organisational praxis (Edwards \& Sen, 2000:612ff.).

\section{The role of religion in social transformation}

It seems as if the late 1990s were a fruitful time for discussing social transformation, especially finding the nexus between religion and social transformation. A few examples will suffice. The South African government perceives and promotes a link between religion and social transformation. The African National Congress's Statement on the Moral Renewal of the Nation (1998:1) quotes former president Nelson Mandela: "In striving for political and economic development, the ANC recognises that social transformation cannot be separated from spiritual transformation." In 1999 a volume of essays was published which explored, from different perspectives, the role of religion in social transformation in Southern Africa. Explaining the interconnectedness of these two phenomena the editors say: "The reason for this is related to both the plight of its people who suffered under the apartheid system and to their indomitable spirit which has given rise to dramatic social transformation and renewed hope for Africa. Here religion has been neither a passive social phenomenon nor a regressive social force.

Rather, it has been proven to be a vital and powerful force for positive change" (Walsh \& Kaufman, 1999:vii). Jacob Olupona, in the introduction to the mentioned volume, elaborates on this point when he argues that "religion, especially Afrikaner civil religion, played a large role in the ideology of apartheid that once upheld the iron curtain of color prejudice, and which for centuries kept millions of Africans from dignity and a humane existence. On the other hand, religion, especially Black liberation theology, contributed greatly to liberating oppressed Black people. This gives hope that religion can play a positive role in the transformation of South Africa in the post-apartheid era" (1999:x).

Arguing from an international perspective, the editors of Religion, Mobilization, and Social Action come to the same conclusion: “... the expectation of religion's loss of influence in personal daily and public affairs has been with us since the days of the founding fathers of social science... There is no evidence that religious influence, in whatever faith tradition, is on the wane" (Shupe \& Misztal, 1998:viii). They conclude that the "religious factor has served as a catalyst, if not an organizing prime mover, for political-economic change in modern countries as diverse as Pakistan, Israel, the United States, Poland, Germany, Malaysia, Ireland, Iran, and Japan" (Misztal \& Shupe, 1998:5). 
It is the hypothesis of this paper that religion does play a significant role in change. Although the secularization thesis predicts the progressive attenuation of religion, there is pervasive evidence to the contrary. Religion is embedded in change processes and in this process religion is not passive (Harper \& LeBeau, 2004:1). It is opportune to seek help from sociologists of religion. According to scholars, there is evidence of religion both promoting and inhibiting change. More to the point, "certain aspects of religion inhibit social change; other aspects challenge the status quo and encourage change" (McGuire, 1997:238).

Religion is inherently conservative and will instinctively protect the status quo. Hence, theories are formulated where religion supports the status quo (e.g. Marx and Engels). According to these scholars, the fundamental basis for social action is material interests (McGuire, 1997:232). Consequently, religion assumes the role of an ideology, "a system of ideas that explains and legitimates the actions and interests of a specific sector of society" (McGuire, 1997:231). This theory can be applied to South Africa prior to 1994.

In predemocratic South Africa the ideology of apartheid protected the interests of the minority White Afrikaans people of the National Party. The Dutch Reformed Church, to which many members of the ruling party belonged, also gave religious legitimisation to the status quo. Religious legitimisation is a process whereby religious organisations and their personnel hold vested interests which they want to protect (McGuire, 997:235). However, religion is also one of the strongest forces that promote change. "Historically, religion has been one of the most important motivations for changes because of its particular effectiveness in uniting people's beliefs with their actions, their ideas with their social lives" (McGuire, 1997:238).

Hence, a rethinking of the Marxian approach emerged, viewing religion as more autonomous from economic overtones. McGuire (1997:240) proposes that religion should be linked to but not reduced to economic interests. The question is no longer whether religion promotes social change, but in what ways and conditions it promotes or inhibits change? McGuire considers three aspects: religious ideas, religious leadership and religious groups (1997:240-248).

"Ideas themselves do not directly effect change. Ideas indirectly influence society through people whose interests lie in pursuing those ideas and applying them to social action. Religious ideas therefore effect social action in two ways: They may form the content of what a group of people try to do; and they may shape people's perception of what their interests are" (McGuire, 1997:240, italics in original). The example of the movement to abolish slavery will suffice.

Another aspect that contributes to social change is the "capacity of religious meanings to serve as symbols of change. Religious symbols frequently present an image of future change. They create a vision of what could be and suggest to believers their role in bringing about that change" (McGuire, 1997:243, italics in original). Secondly, social change often requires a leader who is able to express the "desired change, motivate followers to action, and direct their actions into some larger movement of change. Religion has historically been a major source of such leaders largely because religious claims form a potent basis of authority. The prototype of the change-oriented religious leader is the prophet, whose social role is especially significant" (McGuire, 1997:244, italics in original).

Thirdly, the religious group must be considered. Any religious group, small or big, is a potential force for social change. This potential exists "because religion - especially the religious community - is a source of power, which is a fundamental category in the sociology of religion... Religion is not only an experience of power but often results in the sense of being empowered. Thus, the followers of the charismatic leader may experience a sense of power in their relationship with the leader and with fellow believers that enables them to apply the new order to their social world" (McGuire, 1997:246).

Another potential is the religious group's capacity to unite previously disparate segments of a society. Affiliation to a religion can bridge barriers of tribe, family, nationality and race (McGuire, 1997:247). A last important qualification is the dialectic process between a religious group and its social environment. The group responds to changes in its environment, but also effects changes in the same environment. McGuire developed a model to illustrate this constant dynamic. It is built on two distinctions, namely the relationship between the religious group and the larger society (see y-axis in figure below) and the extent to which the religious group considers itself to be uniquely legitimate (see x-axis in figure below) (1997:147). 


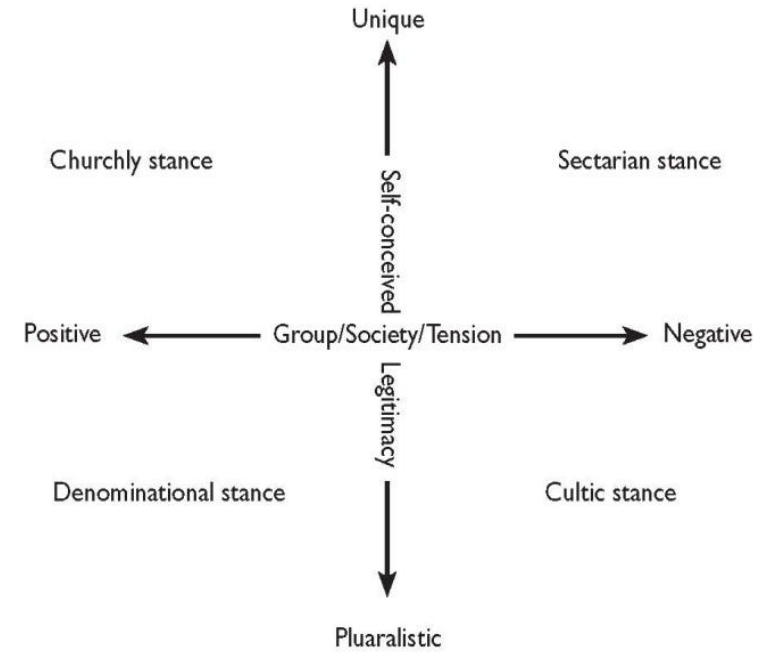

Source: McGuire, 1997:148

"Churchly collectivities consider themselves uniquely legitimate and exist in a relatively positive relationship with society. They do not recognize the legitimacy of claims of any other religious group... The response to competing claims may be to ignore, suppress, or co-opt the competing group. The churchly stance is accepting of society but - to the extent that religion is differentiated from other institutions - it exists in tension with other institutions. Overall, however, a churchly stance tends to support the societal status quo" (McGuire 1997:147-8).

At the same time, the model emphasizes the extent to which the society also accepts the churchly collectivity. "Membership of this kind of group is not considered deviant or unusual" (McGuire 1997:148). "Sectarian religious collectivities consider themselves to be uniquely legitimate; they are in a relatively negative relationship with the dominant society. The sectarian stance does not accept the legitimacy claims of other religious groups." They respond to competing religious groups by withdrawing from their influence, aggressively attacking, or trying to convert and absorb them" (McGuire 1997:148-9). The sectarian stance tends to confirm and protect believers whose worldview differs from that of the dominant society. "Religious collectivities that exist in a positive relationship with society and accept the legitimacy claims of other religious collectivities have a denominational stance. They are perhaps even more generally accepting of society because, with its pluralistic approach, they have no intent or possibility of controlling society" (McGuire 1997:149).

"The cultic stance is characterized by acceptance of the legitimacy claims of other groups but a relatively negative tension with larger society. Like the denominational stance, cultic religious collectivities do not claim to have the truth and they are tolerant of other religious groups. Like sectarian collectivities, cultic groups are a form of social dissent; however, their dissent is likely to be less extreme because of its pluralistic stance" (McGuire 1997:150).

\section{Case study}

Following the above discussion, we now turn to the case study. The question that needs to be asked here is whether religion, specifically the Christian religion, has the potential to influence social transformation. The case study is taken from an area in the Western Cape called the Helderberg Basin. The area will be looked at from an urbanisation perspective. Urbanisation often introduces new challenges, e.g. the demands for land, housing, employment, and it is linked to problems of crime and HIV/Aids. Urbanisation in South Africa is particularly complex because of the legacy of apartheid laws. These laws put artificial constraints on Black South Africans, strictly controlling their influx to "White" areas. One of the central thrusts of former government policy was to prevent Africans moving to urban areas (Wilson \& Ramphele, 1994:207). With the abolition of influx control in the mid-1980s urbanisation rates increased - especially to the large metropolitan areas in search of employment. 


\section{Demographics of the Basin}

Helderberg Basin is a community of approximately 150,000 people about 50 kilometres east of the Cape Town Central Business District. The demographics from Census 1996 and 2001 indicate a growth in population of about 33,000 people. The Black population group as percentage of the total population grew by $11.5 \%$ (13.3\% to $24.8 \%$ ) from 1996 to 2001 .

Basic demographic indicators for the Helderberg Basin taken from Census 2001 are as follows:

- Population: 149,003

- Population groups:

Black $-24.8 \%$

Coloured $-42.6 \%$

White $-32.2 \%$

- Age

$0-19-34.4 \%$

$20-34-26.7 \%$

$35-49-19.7 \%$

50 and older $-19.2 \%$

- Average income per household: R 95,321 per

year

- Language

Afrikaans $-59.3 \%$

isiXhosa $-21.4 \%$

English $-16.2 \%$

- Religious affiliation

Christian $-85 \%$

Islam - 4\%

No religion $-10 \%$

\section{Effects of Urbanisation}

The average income per household in 1996 was R58256. Taking into account the inflation, this income increased to R70088 by 2001, an increase of only $20.3 \%$ from 1996 . Coloured and Blacks earn, on average, less than the Whites. The total percentage of informal dwellings in the Basin is $20.7 \%$. There are areas that are almost exclusively informal dwellings - for example - the Broadlands with $98 \%$, an area within Lwandle with $88 \%$ and Sir Lowry's Pass with 41\%. The areas with the highest unemployment are Bridgewater Extention with $42 \%$, Lwandle with $38 \%$ and Nomzamo with $31 \%$.

The crime data from the South African Police Service on sexual (rape, attempted rape) and other violent crimes (indecent assault, common assault, assault with the intent to cause grievous bodily harm) shows that the area with the highest incidence of sexual crime is in Sir Lowry's Pass, followed by Lwandle. The areas with the highest incidence of violent crime are Sir Lowry's Pass and Mountainview. Overcrowding and unemployment are a by-product of urbanization. Some areas suffer with overcrowding and unemployment more than the others. The crime rate is higher where this is the case.

\section{The Christian religion in the Basin}

Three sets of information from the Basin will illustrate the point of the potential religion could have in the Basin. The three variants are the distribution of places of worship, affiliation with the Christian religion and the perception of religion measured in two communities most hit by urbanisation in the Basin, Sir Lowry's Pass and Lwandle. Firstly, a summary of all the places of worship is given at the top of the next page. There are 244 places where people worship. Congregants utilise different venues for this purpose, e.g. houses, formal buildings, schools or other places. $92.6 \%$ of all places of worship are Christian, followed by 5.7\% Traditional African Belief. There is one church for every 660 people in the region as a whole. There are more churches per capita in areas of lower socio-economic status.

There are several possible reasons for this. People in higher socio-economic areas have the means, for example, to travel to churches further away from them. Concomitantly, churches in higher socio-economic areas possibly have the infrastructure (full-time pastors, telephones, fax lines, email and buildings) to serve 
more people. On the other hand, people in lower socio-economic areas have to walk to the church of their preference. For example, there are 65 churches in Macassar, meaning one church for every 376 people; 2 churches in Heldervue, meaning one church for every 1167; 26 in Ezimbacwini, meaning one church for every 329, and lastly 20 in Sir Lowry's Pass village, meaning one for every 110 people.

Secondly, the affiliation to the Christian religion in the Basin, according to Census 2001, is $85.5 \%$. The national figure is $79.8 \%$. This percentage is slightly down from $88.7 \%$ in 1996 . Thirdly, interesting features were revealed in the C-Index of the needs analysis in the two areas. Schutte identified 13 facilities 6 that are crucial to any community (Schutte 2000:23ff.).

\begin{tabular}{|c|c|c|c|c|c|c|}
\hline \multicolumn{7}{|c|}{ Places of worship } \\
\hline & House & $\begin{array}{c}\text { Formal church } \\
\text { building }\end{array}$ & School building & Other & Total & $\%$ \\
\hline Christian & 39 & 99 & 34 & 54 & 226 & 92.6 \\
\hline Muslim & 0 & 3 & 0 & 2 & 5 & 2 \\
\hline Hindu & 0 & 0 & 0 & 0 & 0 & 0 \\
\hline Jewish & 0 & 1 & 0 & 0 & 1 & 0.4 \\
\hline Traditional African Belief & 7 & 0 & 0 & 7 & 14 & 5.7 \\
\hline Other religions & 0 & 1 & 0 & 0 & 1 & 0.4 \\
\hline Total & 43 & 104 & 34 & 64 & 244 & 100 \\
\hline
\end{tabular}

\section{C-Index: Sir Lowry's Pass}

A graph of the C-Index of the area of Sir Lowry's Pass is given below. The scale varies between 0 and 11, where 11 indicates a high level of satisfaction. It appears that the five facilities and services rated highest were water, food, energy and religion. Religion is the sector which is viewed most positively.

\section{C-Index: Lwandle}

A graph of the C-Index of the area of Lwandle is given in the next column. Compared to Sir Lowry's Pass, the facilities and services are viewed more positively. Again religion stands out and provides for opportunities to enter the community. It seems clear from the three variants that the Christian religion is in an excellent position to influence the process of social transformation.

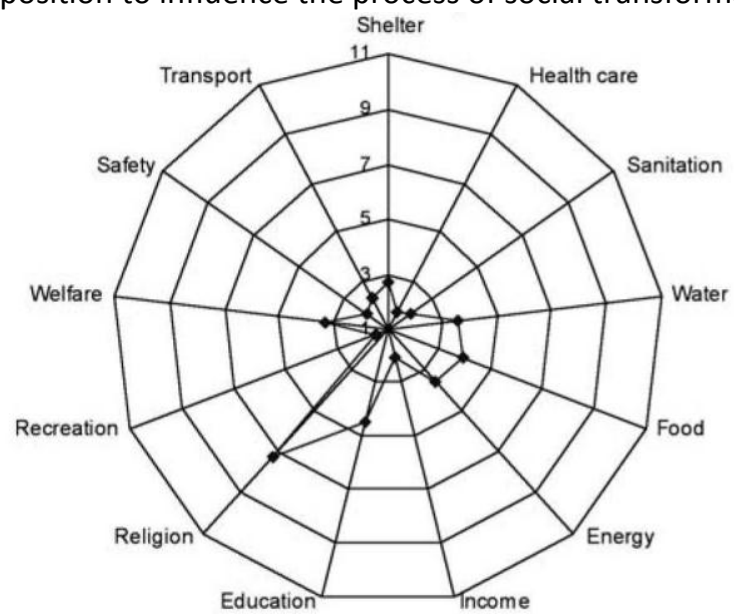

C-Index Sir Lowry's Pass

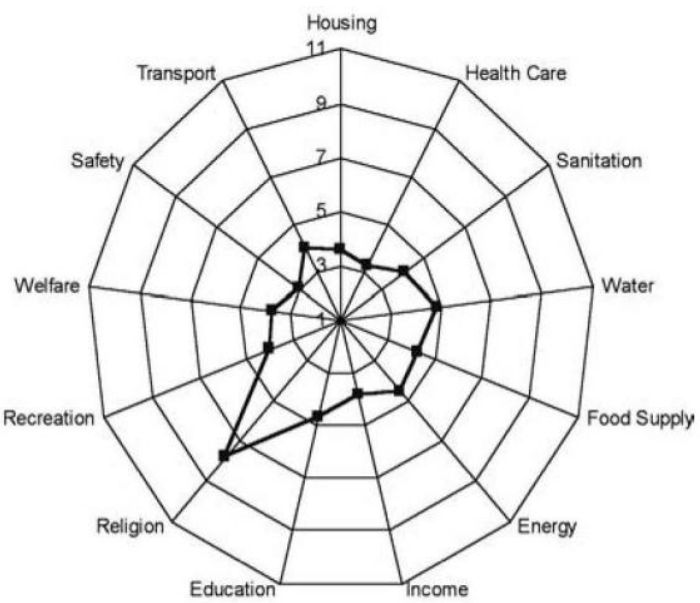

C-Index Lwandle

\section{Conclusion}

In conclusion, does the Christian religion have the potential to influence the effects of urbanisation, namely income distribution, housing, unemployment and crime? The three sets of information presented on the Christian religion definitely indicate that the Christian religion does have the potential to promote change. Currently, there are initiatives from both church and business leaders to effect transformation in the community. Whether 
they are successful will depend on:

1. The values/ideas which they employ; the symbols and images they use. Religious ideas about poverty, women and family, the environment, the local community, safety and security, peace, reconciliation, social justice, equity etc. will have an influence.

2. Leadership - leadership that expresses the desired change and lives it, leadership that 'walks the talk'. These leaders must be prophets who declare the path, affirm the values and act as symbol senders. Alternatively, they can be a networking organization characteristic of the new social movements, mirroring, and counteracting, the networking logic of domination in the informational society. They need to have the capacity to function both as a resistance identity on behalf of the unemployed, victims of HIV/Aids, crime, racism, sexism, and as a project identity, thus being proactive.

3. Their capacity to be inclusive and effect unification will create the space for change.

4. The initiative must integrate deep spiritual transformation with social transformation.

5. The potential of the Christian religious group. The Christian religion does have the potential to promote change. The internal dynamics of religious communities (see Lategan, 1991: 10-16) in the Basin might also influence this potential.

6. The dialectic relationship of the Christian group with the larger society. Both the sectarian and cultic stance limit the potential influence. The stance with the most potential is the churchly stance, provided the group does not settle for only supporting the status quo.

\section{Notes}

1 Paper presented at the 31st International Conference of the International Council for Social Welfare (ICSW) held in Kuala Lumpur, Malaysia from 16-20 August 2004.

2 Pearce (2003) provides a short history of this organisation.

3 Globalization can be characterised as "the widening, deepening and speeding up of worldwide interconnectedness in all aspects of contemporary social life, from the cultural to the criminal, the financial to the spiritual" (Held et al. 1999:2 in Castles, 1999:7) and defined as "a process which embodies a transformation in the spatial organisation of social relations and transactions - assessed in terms of their extensity, intensity, velocity and impact - generating transcontinental or interregional flows and networks of activity, interaction, and the exercise of power" (Held et al. 1999:16 in Castles, 2000:7).

4 The official definition of Census 2001 for an unemployed person is: "An unemployed person according to the official definition is a person between the ages of 15 and 65 with responses as follows: 'No, did not have work'; 'Could not find work'; 'Have taken active steps to find employment'; 'Could start within one week, if offered work'." (www.statssa.gov.za).

5 All the answers of respondents in Census 2001 were indexed into 67 groups, 62 religious groups and 5 other categories (e.g. "not stated").

6 These are considered to be the cornerstones necessary for the survival of any community. The first six refer to individual needs for survival, while the remaining seven are social needs related to the interaction of humans. They are shelter, health care, sanitation, water, food, energy, safety, income, education, recreation, religion, welfare and transport. 


\section{References}

Barnhart, CL \& Barnhart, RK 1982. The World Book Dictionary. Volume two L-Z. Chicago: World Book-Childcraft International, Inc.

Castles, S 1999. "Development, Social Transformation and Globalisation”. Paper delivered CAPSTANS workshop 23-25 June 1999, 1-18.

Castells, M 1996. The Rise of the Network Society. Oxford: Blackwell Publishers, Ltd.

Castells, M 1997 The Power of Identity. Oxford: Blackwell Publishers, Ltd.

Curry, T Jiobu, R \& Schwirian, K 1997. Sociology for the 21st Century. New Jersey: Prentice-Hall, Inc.

David, G 2000 “From Social Development to Transformation”. Social Development 22/1, 9-14.

Drucker, PF 1994. "The Age of Social Transformation". The Atlantic Monthly 274/5, 53-80 (available on www.theatlantic.com/issues/95dec/chilearn/drucker.htm ).

Edwards, M \& Sen, G 2000. "NGOs, social change and the transformation of human relationships: a 21stcentury civic agenda". Third World Quarterly, 21/4, 605-616.

Erasmus, JC \& Hendriks, HJ 2003. “Religious Affiliation in South Africa early in the New Millenium: Markinor's World Values Survey". Journal of Theology for Southern Africa 117, 80-96.

Erasmus, JC 2000. 'n Ondersoek na die Godsdienstige Topografie van Suid-Afrika: 'n Vergelyking van Sensus '96 met dié van 1911-1991. Unpublished Masters thesis. University of Stellenbosch.

Froise, M \& Hendriks, HJ 1999. South African Christian Handbook 1999-2000. Welkom: Christian Info.

Groenewald, C 2000. "Social Transformation: Between Globalization and Localization". Scriptura 72 (2000), 1529.

Harper, CL \& LeBeau, BF 2004. "Social Change and Religion in America. Thinking Beyond Secularization". http://are.as.wvu.edu/sochange.htm : 1-12.

Hendriks, HJ \& Erasmus, JC 2001. "Interpreting the new religious landscape in post-Apartheid South Africa". Journal of Theology for Southern Africa 109, 41-65.

Hendriks, HJ 2003. "The Future of the Church and the Church of the Future". Inaugural speech as professor and head of the department of Practical Theology \& Missiology, University of Stellenbosch.

HSRC 2000. Media release from the Human Sciences Research Council, 14 November 2000.

http://www.hsrc.ac.za/media/2000/11/20001114-1.html

Lategan, B 1991. "Socio-Religious change in South Africa”. The South African Journal of Sociology 22/1, 10-16.

McGuire, MB 1997. Religion - the social context. Belmont: Wadsworth Publications Co.

Misztal, B \& Shupe, A 1998. "Fundamentalism and Globalization: Fundamentalist Movements at the Twilight of the Twentieth Century". Shupe, A \& Misztal, B (ed.) Religion, Mobilization, and Social Action, Westport: Praeger Publishers.

Moral Regeneration - Moral Regeneration Movement: Promotional Booklet. Pretoria: Government Printer.

Olupona, J 1999. "Introduction" Walsh, TG \& Kaufman, F (ed.). Religion and Social Transformation in Southern Africa, Minnesota: Paragon House. 
Pearce, T 2003. Leadership for Holistic Transformation - towards a model for Cape Town, South Africa and Beyond. Unpublished Masters short thesis in Organizational Leadership at Cornerstone Christian College.

Schutte, DeW 2000. People First - Determining Priorities for Community Development, Parow East: Ebony Books.

Shupe, A \& Misztal, B (ed.) 1998. Religion, Mobilization, and Social Action, Westport: Praeger Publishers.

Stanley, L 1997. "Social Transformation? Exploring Issues in Comparison, Development and Change". Editorial and Call for Papers, Sociological Research Online (http://www.socresonline.org.uk/copy.html ).

Statistics South Africa. Census 2001. www.statssa.gov.za .

Swart, I "The Imperative of Development: A Third Public Challenge to Computerised Biblical Scholarship". Bible and Computer, edited by J. Cook. The Stellenbosch AIBI-6 Conference. Proceedings of the Association Internationale Bible et Informatique "From Alpha to Byte". University of Stellenbosch 17-21 July, 2000. Leiden: Brill, 593-613.

Taylor, J 1998. "Transformation and development: a South African perspective". Community Development Journal 33/4, 292-300.

Terreblanche, SJ 2002. A History of Inequality in South Africa, 1652-2002. Pietermaritzburg: University of Natal Press.

Tyndale, W 2000. "Faith and economics in 'development': a bridge across the chasm?" Development in Practice 10/1, 9-18.

Walsh, TG \& Kaufman, F (ed.) 1999, Religion and Social Transformation in Southern Africa, Minnesota: Paragon House.

Wilson, F \& Ramphele, M (ed.) 1994. Uprooting poverty. The South African Challenge. Cape Town: David Philip.

Wint, E \& Ngcobo, T 2000. "We don't have to go to bed on phuthu alone: A case of transformation in Colenso". Journal of Social Development in Africa 15/2, 93-114. 